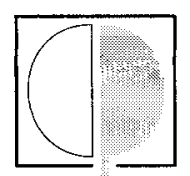

\title{
Biology and management of Melanagromyza obtusa (Malloch) (Diptera:Agromyzidae)
}

\author{
T.G. Shanower ${ }^{\ddagger}$, S.S. Lal ${ }^{\dagger}$ and V.R. Bhagwat* \\ *International Crops Research Institute for the Semi-Arid Tropics (ICRISAT), Patancheru 502 \\ 324. Andhra Pradesh, India and 'Division of Entomology, Indian Institute of Pulses \\ Research (IIPR), Kanpur 208 024, Uttar Pradesh, India
}

\begin{abstract}
Melanagromyza obtusa (Malloch) (Diptera:Agromyzidae), the pigeonpea pod fly, is a key pest of pigeonpea [Cajanus cajan (L.) Millsp.] throughout south and south-east Asia. Females deposit eggs in the green pods of pigeonpea and other host plants, and the developing larva feeds on and destroys the unripe seed. Substantial yield losses have been attributed to this pest in several countries. Pest management strategies for the pigeonpea pod fly have emphasized chemical control and host-plant resistance. This paper reviews the literature on the distribution, host plants, biology, natural enemies and control strategies for this pest. Priorities for future research are also suggested. (C) 1998 Elsevier Science Ltd. All rights reserved
\end{abstract}

Keywords: pigeonpea; pod fly; distribution; natural enemies; control strategies

Melanagromyza obtusa (Malloch) (Diptera:Agromyzidae), the pigeonpea [Cajanus cajan (L.) Millspaugh] pod fly, is one of the two most important pests of pigeonpea (Lal and Yadava, 1987; Lateef and Reed, 1990). Pigeonpea is grown throughout the tropics but most widely in south and south-east Asia, where it is a preferred source of vegetable protein (Nene and Sheila, 1990). It is also an important crop in eastern and southern Africa. The genus Melanagromyza includes 20 species some of which are pests of other legumes. Only two species, $M$. obtusa and $M$. chalcosoma Spencer, feed on pigeonpea (Spencer, 1973). Melanagromyza chalcosoma, which also feeds on cowpea (Vigna unguiculata Walp.) and is limited geographically to eastern and southern Africa (Spencer, 1973), is similar biologically to $M$. obtusa.

This paper reviews the literature on the biology, ecology and management of $M$. obtusa. The sources are widely scattered, frequently difficult to obtain, and include unpublished or limited distribution material. Much of the research has been conducted in India but will be of relevance to countries where $M$. obtusa is a pest. In addition, research on pest management strategies for $M$. obtusa may be relevant to the important but less well-studied $M$. chalcosoma (Minja et al., 1996). In the final section of this paper priority areas for future research are suggested.

¥Present address: USDA/ARS, 1500 N. Central Ave., Sidney, MT 59270, USA.

\section{Distribution and host plants}

Melanagromyza obtusa has been reported from Asia and eastern Africa (Table 1), although its presence in the latter region is disputed. In Asia, it is recorded throughout the area bounded by Pakistan and Japan in the north, and Sri Lanka and Papua New Guinea in the south. In India, M. obtusa is widely distributed but is more prevalent in northern than in southern States (Sehgal, 1990). It has not been reported from several countries within the Australasian region (e.g.

Table 1. Geographic distribution of $M$. obtusa

\begin{tabular}{ll}
\hline Country & \multicolumn{1}{c}{ Reference } \\
\hline Bangladesh & Kabir, 1978 \\
India & Maxwell-Lefroy, 1906 \\
Indonesia & de Meijere, 1922 (in Spencer, 1973) \\
Japan & Singh and Ipe, 1973 \\
Kenya* & Le Pelley, 1959 \\
Malaysia & Sasakawa, 1963 \\
Myanmar & Ahmad, 1938 \\
Nepal & Neupane, 1993 \\
Pakistan & Ahmad, 1982 \\
Papua New & Singh and Ipe, 1973 \\
Philippines & Litsinger, 1987 (pers. commun, in Talekar, 1990) \\
Sri Lanka & Thevasagayam and Canagasigham, 1960 \\
Taiwan & Malloch, 1914 \\
Thailand & Talekar, 1990 \\
Uganda* & Le Pelley, 1959 \\
Vietnam & Hong et al., 1992 \\
\hline
\end{tabular}

^Doubtful, see text. 
Cambodia, China, Australia), perhaps due to the small areas under pigeonpea cultivation, although it is probably present since it is found in adjacent countries. The uncertainty regarding the presence of $M$. obtusa in eastern and southern Africa is complicated by the occurrence of the morphologically and ecologically similar $M$. chalcosoma. Spencer (1973) and Talekar (1990) both cite earlier reports of eastern and southern African locations (Table 1) as part of the authentic geographic range of $M$. obtusa. Reed and Lateef (1990) express strong doubt that $M$. obtusa is present in Africa and consider such reports to be misidentifications. Recent pigeonpea pest surveys in Kenya, Malawi, Tanzania and Uganda reported only $M$. chalcosoma infesting pigeonpea pods (Minja et al., 1996) but this is a question which needs to be clarified.

Melanagromyza obtusa has a narrow host range and has only been recorded from five genera all in the Papilionaceae (Table 2). Pigeonpea and Flemingia macrophylla are the only commercially cultivated host plants. Fleminga macrophylla, used as a host plant in the production of lac, is heavily attacked by $M$. obtusa (Kulkarni, 1966). Reports of five other agriculturally important plant species as hosts for $M$. obtusa are questioned. Venugopal and Venkataramani (1954), Patel and Verma (1973) and Sharma and Singh (1984) have reported $M$. obtusa on okra [Abelmoschus esculentus (L.) Moench (= Hibiscus esculentus L.)] (Malvaceae). Sehgal (1987) believed that these authors had mistakenly identified $M$. hibisci Spencer (Agromyzidae) as $M$. obtusa and that okra is not a host for $M$. obtusa. This did not end the confusion and recent publications (e.g. Talekar, 1990) continue to report okra as a host plant for $M$. obtusa. Safflower (Carthamus tinctorius L.) (Asteraceae) and sesame (Sesamum indicum L.) (Pedaliaceae) have also been incorrectly reported as hosts for $M$. obtusa in India (Abraham et al., 1973; David and Janagarajan, 1969; Husain and Khan, 1965). Neither plant is now considered to be an authentic host for $M$. obtusa (V.K. Sehgal, pers. commun.). There are also reports of $M$. obtusa in pods of Vigna radiata (I.) R. Wilczek (Spencer, 1973) and V. unguiculata (Mehrotra et al., 1989). Confirmation of the suitability of these hosts for $M$. obtusa survival and development is needed before they can be considered as host plants.

\section{Growth and development}

Ahmad (1938) provided a very detailed account of many aspects of $M$. obtusa biology. Melanagromyza obtusa females oviposit in the tender pods of the host plant. The eggs, glistening white when laid, are tearshaped and measure approximately $1.0 \times 0.2 \mathrm{~mm}$ (Ipe, 1974). Females lay between 30 and 40 eggs, although individuals may produce as many as 79 eggs (Ahmad, 1938; Bindra and Singh, 1972; Singh and Rai, 1984).

At constant temperatures under controlled conditions the egg stage requires 3 days at $27^{\circ} \mathrm{C}$ and 9 days at $18^{\circ} \mathrm{C}$ (Ahmad, 1938). Other workers have reported egg development times within this range (David, 1964; Singh and Rai, 1984). Newly hatched larvae (ca. $0.5 \mathrm{~mm}$ long) locate the developing seed and may feed on the exterior for a short time before boring through the seed coat. Larvae feed on the developing cotyledons and pass through three stadia before pupating (Ipe, 1974). A single pigeonpea seed is sufficient food for the larva to complete development, although occasionally more than one seed may be attacked (Ahmad, 1938). Melanagromyza obtusa larvae crawl out of the seed and cut a 'window' in the pod wall before pupating. The pupae are brown and ca. $2.5 \mathrm{~mm}$ in length. Pupation occurs in the open lumen of the locule. Spencer (1973) states that $M$. obtusa can be distinguished from $M$. chalcosoma because the latter pupates within the seed itself. There has been no other report of this. Pupae, brown and ca. $2.5 \mathrm{~mm}$ in length, require 9-23 days to complete development (Ahmad, 1938).

The total larval and pupal development period requires 6-11 and 9-23 days respectively (Ahmad, 1938). Slightly shorter development times have been

Table 2. Host plants of Melanagromyza obtusa 
reported and may reflect higher temperatures experienced in the field (Bindra and Singh, 1972; Singh and Rai, 1984). Temperature-dependent growth rates (Figure 1) have been calculated for each of the immature stages of $M$. obtusa using data from Ahmad (1938), Ipe (1974) and Singh and Rai (1984). Linear regression analysis of egg development times at different temperatures $\left(y=0.371+0.027 x ; r^{2}=0.97\right)$ indicates that the threshold temperature for egg development is $13.7^{\circ} \mathrm{C}$. Similar analyses for larval $\left(y=0.114+0.010 x ; r^{2}=0.60\right)$ and pupal $(y=0.123+$ $0.009 x ; r^{2}=0.97$ ) development rates produced the following developmental thresholds: larvae $=11.4^{\circ} \mathrm{C}$ and pupae $=13.7^{\circ} \mathrm{C}$. These thresholds, and the developmental rates from which they are derived, need to be verified with a complete and independent data set.

The window cut by the fully grown larva, and covered only by translucent epidermal cells, serves as the adult fly's exit from the pod. It is likely that adults orient to the exit through a positive phototactic response (Ahmad, 1938). Adults are relatively short lived. At low temperatures adults live for fewer than 12 days, while at higher temperatures longevity declines to 5-7 days (Ahmad, 1938). Adults maintained without food live about half as long as adults supplied with honey (Ahmad, 1938).

\section{Oviposition}

Adults mate 2-5 days after emergence and females select a site for oviposition. Females lay single eggs and require 2-4 min to deposit each egg (Ipe, 1974). Generally, a single egg is laid per locule, although as many as 22 eggs have been found in a single pod (Ipe, 1974). It is not known whether females 'mark' oviposition sites to prevent subsequent females from depositing eggs in the same locule. Ipe (1974) reports that an average of four eggs per pigeonpea pod were found in a heavily infested field.

Sithanantham et al. (1981) reported a slight but non-significant tendency for more $M$. obtusa eggs to be found in pods in the upper third of pigeonpea
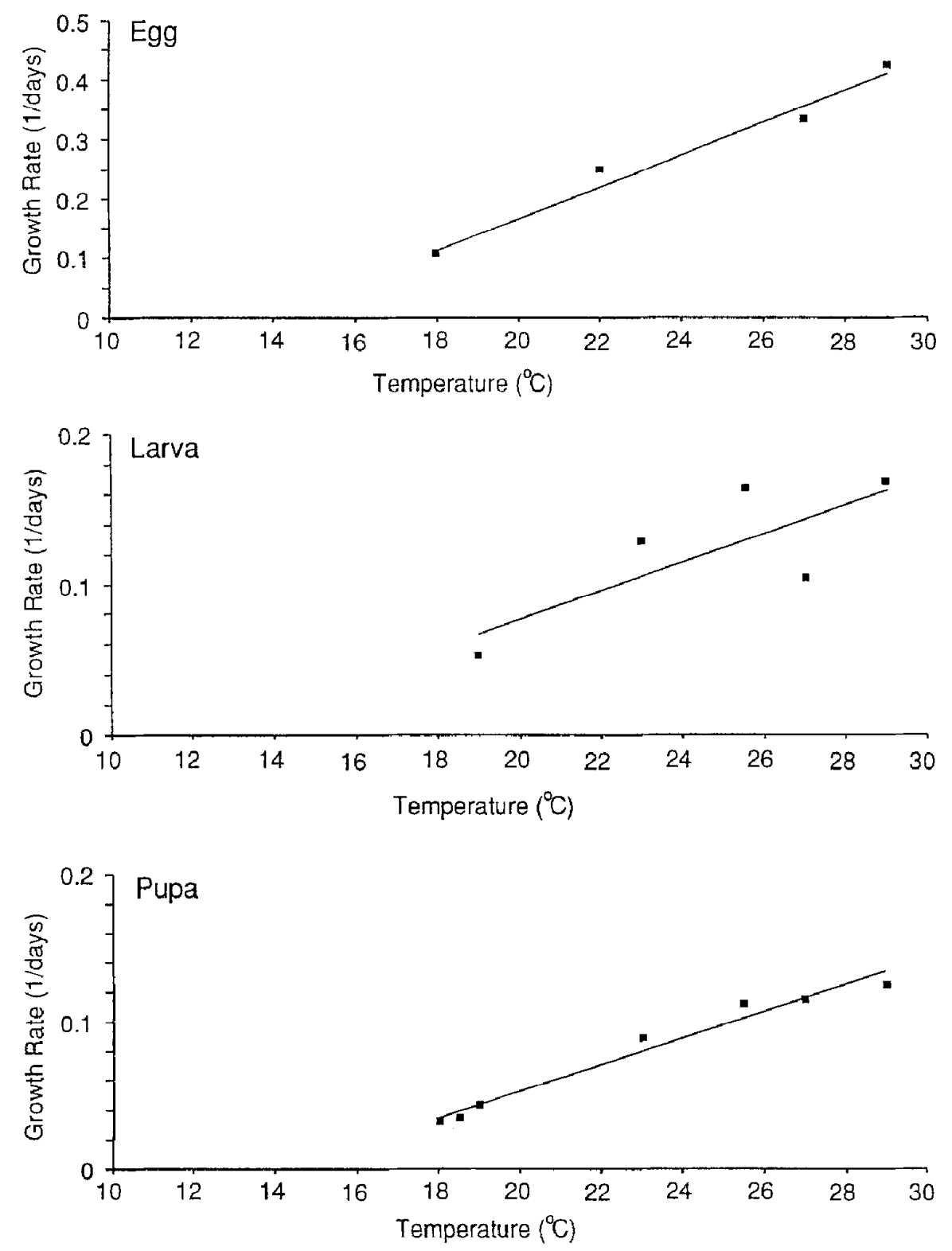

Figure 1. Growth rates for Melanagromyza obtusa eggs, larvae and pupae (data from Ahmad, 1938; Ipe, 1974; Singh and Rai, 1984). 
plants compared to the middle or lower portions. Kaushik et al. (1988) divided plants into four areas: upper, upper-middle, lower-middle and lower. They found $70 \%$ of eggs in pods from the middle two regions of the plant, and fewest eggs in pods from the upper portion. These authors noted that the middle portion of the plant bears the majority of the pods but did not account for the difference in pod number between areas. It may be that the number of available pods is a more important ovipositional cue for females than the location of pods on the plant. The preference for pods located in different areas of the plant probably does not reflect a preference for pods of specific ages (see below). The most commonly cultivated pigeonpea cultivars are indeterminate in growth and have pods of different ages simultaneously available in upper, middle and lower portions of the plant.

The 'within-pod' distribution of pod fly eggs has also been investigated. Several workers have noted that more eggs are placed near the ventral suture than either lateral areas or near the dorsal suture of pods (Sithanantham et al., 1981; Singh et al., 1982; Lal et al., 1988). In this position eggs are furthest from the developing seed and may be less likely to be crushed (Sithanantham et al., 1981). This position, on the underside of the pod, may also be less accessible to some natural enemies. Females also select locules for oviposition in a non-random manner. Singh et al. (1982) found that the fewest eggs were placed in the basal locule, with equal numbers in the middle and apical locules. Other workers reported that middle locules are favoured, and that fewest eggs are found in apical locules (Lal et al., 1988).

Pod age and size have been shown to influence the selection of oviposition sites by $M$. obtusa. Singh et al. (1982) reported that younger ('green') pods are preferred to older pods for oviposition. Lal et al. (1988) found that as the season progressed, females selected younger pods for oviposition. In January, females preferred 30-35-day-old pods while in April, females preferred 10-20-day-old pods (Lal et al., 1988). These workers believed that as daily mean temperatures increased from January to April, pod growth and, hence suitability to pod fly, changed. It may also be that pod fly populations increase during this same period, forcing females to select younger pods for oviposition.

Veda et al. (1975) were the first to note a positive correlation $(r=0.24)$ between pod width and the percentage of infested grain. Strong correlations have been recorded between both pod width $(r=0.98)$ and pod length $(r=0.99)$, and per cent grain damage in another study (Thakur et al., 1989). Lal et al. (1988) noted that small pods had less pod fly damage than larger pods while Tripathi and Prohit (1983) found that small pods were more heavily damaged. All of these reports assume that greater damage levels reflect preferential selection by females.

\section{Seasonality}

The seasonal population dynamics of $M$. obtusa are governed by its restricted host range and feeding niche. In India, pigeonpea pods are available in the field from approximately October to April. Pod fly infestations can increase rapidly over a relatively short period (Rangaiah and Sehgal, 1986). As temperatures decline in December and January, $M$. obtusa ovipositional activity also declines (Ahmad, 1938; Srivastava et al., 1991). However, infestations increase along with temperatures and pigeonpea which matures in March or April is often heavily damaged (Lal et al., 1981; Yadava et al., 1983a).

The population dynamics of $M$. obtusa on host plants other than pigeonpea have not been well studied. Kulkarni (1966) found pods of F. macrophylla infested from mid-November through to midFcbruary. This plant supports $M$. obtusa in uncultivated areas and can produce flowers and pods in the summer (Sithanantham and Sehgal, 1985). Khokhar et al. (1987) found up to $19 \%$ of pods of Rhyncosia minima infested with eggs, larvae and/or pupae of $M$. obtusa between April and November. Thus, it appears that $M$. obtusa survives in the off-season on alternative host plants.

\section{Damage, yield loss and monitoring}

Melanagromyza obtusa is of economic importance only in the larval stage. Larvae damage pigeonpea and reduce yield by feeding on and destroying the developing seed. Damaged seeds do not germinate (Singh and Singh, 1986), and may or may not be consumed, depending on the level of damage. Even slightly damaged seed receives a lower price in the market. Damage and yield losses vary across locations, seasons and cultivars, and it is difficult to estimate losses due to this pest. A large number of reports of damage to pigeonpea by $M$. obtusa is available. Insect damage to pigeonpea is often reported in terms of pod damage. For $M$. obtusa this is not a useful indication of damage or yield loss since there may be five or more seeds per pod and $M$. obtusa rarely damages all of the seeds in a pod. For this reason Bindra and Jokhmola (1967) suggested that pod fly damage be reported in terms of grain or seed damage.

Two methods have been suggested for computing yield loss in pigeonpea from information on $M$. obtusa damage. The difference in the methods depends on the suitability of damaged grains for human consumption. If infested grains are not fit for consumption, as Gangrade (1965) stated, then yield loss is equal to the percentage of damaged seeds (e.g. $16 \%$ damaged seeds would equal $16 \%$ yield loss). This figure would represent the maximum yield loss as each seed damaged would be considered unusable. Gangrade (1965) used this reasoning but underestimated yield losses by using the weight rather than the number of damaged seeds and dividing by the total weight, including damaged seeds, in a sample.

Bindra and Jokhmola (1967) noted the problem in Gangrade's method and suggested that damaged seeds were not a total loss. They calculated that yield loss is equal to the reduction in weight of damaged seeds divided by the proportion of $M$. obtusa 
damaged seeds:yield loss $(\%)=[($ wt of undamaged seeds - wt of damaged seeds)/wt of undamaged seeds]/proportion of seeds damaged by $M$. obtusa. The reduction in seed mass due to $M$. obtusa is calculated using an equivalent number of damaged and undamaged seeds.

It is unclear which method is more accurate although many authors have followed the latter methodology to express yield loss (see below). The first method is calculated more easily since pest incidence (percentage of damaged seeds) equals yield loss. It may also be more accurate if, as is likely, damaged seeds are discarded during the harvesting and milling process. If damaged seeds are in fact utilized for human or animal consumption then the second method will be more accurate. The second method requires the additional step of calculating the reduction in seed mass due to $M$. obtusa.

Most of the data on $M$. obtusa damage and yield loss has been obtained from trials on research stations. Table 3 provides a selected list of published reports of sced damagc by $M$. obtusa at rescarch stations in India, Taiwan and Vietnam. Results in this table indicate seed damage of between $2 \%$ and more than $90 \%$, with large variations across locations, seasons and genotypes. While useful, research stations rarely provide conditions similar to farmers' fields. ICRISAT (International Crops Research Institute for the Semi-Arid Tropics) and ICAR (Indian Council of Agricultural Research) entomologists surveyed pigeonpea fields in India for insect pest damage from 1975 to 1981 . It was observed that $M$. obtusa was a more serious pest in the northern and central areas of India than in the southern or northwestern areas. Nonetheless, seed damage of more than $30 \%$ was reported from some districts of the southern state of Andhra Pradesh (Lateef and Reed, 1983). Several other publications have also reported $M$. obtusa damage levels in farmers' fields. Extensive surveys carried out in the northern state of Uttar Pradesh revealed that pod fly damage in farmers' fields ranged from 14 to $46 \%$ of pigeonpea seeds (Lal et al., 1992). In Madhya Pradesh, $M$. obtusa was recorded damaging up to $20 \%$ of pigeonpea seeds in farmers' fields (Odak et al., 1976; Sithanantham and Singh, 1986). Seed damage due to pod fly ranged from 2.6 to $11 \%$ in 11 districts of Gujarat over a 2 year period (Kabaria et al., 1988). Pod fly is the most destructive pest of pigeonpea in northern Vietnam, causing extensive losses in pigeonpea yields in four Provinces (Hong et al., 1992). The conclusion from both on-farm and on-station observations (Table 3 ) is that $M$. obtusa regularly causes substantial but highly variable yield losses in pigeonpea.

Because all of the immature stages of $M$. obtusa occur within the developing pod it is difficult to monitor populations in a non-destructive manner. Several workers have tried to develop methods to monitor adult populations. Sithanantham et al. (1988) evaluated a wide variety of trap designs, colours, attractants and even virgin male and female flies. Although they recorded positive attraction to ethanol and ammonium sulphide, the response was too weak to be considered useful for monitoring field populations. More recently, Mohan et al. (1994) developed a simple sticky trap for monitoring pod fly in the field, and reported catching up to 60 flies per week. The trap developed by Mohan et al. caught more than $6 \times$ the number of adult flies caught in the traps developed by Sithanantham et al., but whether these traps will monitor field populations accurately is unknown. Placing traps in different fields at different times of the year and correlating the number of adults caught with the density of $M$. obtusa eggs would provide an indication of the traps usefulness as a monitoring tool.

\section{Natural enemies}

The only natural enemies of $M$. obtusa reported thus far are parasitic Hymenoptera. No predators, pathogens or non-hymenopterous parasitoids are known. At least 14 species of Hymenoptera have been

Table 3. Selected reports of pigeonpea (Cajanus cajan) seed yield losses due to Melanagromyza obtusa

\begin{tabular}{|c|c|c|c|}
\hline Reference & Year of research & Location $^{1}$ & Loss attributable to $M$. obtusa \\
\hline Bindra and Jokhmola, 1967 & $1955-56$ and $1957-58$ & Jabalpur, Madhya Pradesh & $4-43 \%$ grain damage in 43 genotypes \\
\hline Gangrade, 1963 & $1959-60$ and $1960-61$ & Jabalpur, Madhya Pradesh & $13-87 \%$ grain damage in different flushes of 4 cultivars \\
\hline Rawat and Jakhmola, 1967 & 1966 & Jabalpur, Madhya Pradesh & $2-11 \%$ grain yield loss in 8 cultivars \\
\hline Patel and Patel, 1983 & $1975-76$ & Anand, Gujarat & $7-23 \%$ grain damage in 14 genotypes \\
\hline Reddy et al., 1981 & $1978-79$ & Varanasi, Uttar Pradesh & $20-46 \%$ seed damage in 16 long duration cultivars \\
\hline Bhosale and Nawale, 1985 & $1978-79$ & Rahuri, Maharashtra & $\begin{array}{l}5-15 \%, 8-20 \% \text { and } 12-31 \% \text { grain damage in early } \\
\text { (11 lines), medium (22 lines) and late ( } 7 \text { lines) } \\
\text { genotypes }\end{array}$ \\
\hline Naresh et al., 1983 & 1980 & Hisar, Haryana & $4-12 \%$ grain damage in 8 cultivars \\
\hline Naresh and Singh, 1984 & 1980 & Hisar, Haryana & $<2 \%$ grain damage in cultivar Prabhat (early) \\
\hline Pandey et al., 1984 & $?$ & Navgaon, Rajasthan & $16-45 \%$ grain infestation in 18 cultivars \\
\hline Patnaik and Patnaik, 1985 & $1983-84$ & Sambalpur, Órissa & $13-30 \%$ grain damage in 7 early genotypes \\
\hline Bhalani and Parsana, 1992 & 1984 and 1986 & Junagadh, Gujarat & $\begin{array}{l}2-12 \% \text { and } 4-10 \% \text { grain damage in extra-short } \\
\text { (33 lines) and short ( } 12 \text { lines) genotypes }\end{array}$ \\
\hline Yadava et al., 1988 & $1984-85$ and $1985-86$ & Kanpur, Uttar Pradesh & $9-30 \%$ grain damage in 4 cultivars \\
\hline Veda and Shaw, 1992 & $1988-89$ & Jhabua, Madhya Pradesh & $0-3 \%$ grain loss in ICPL 87 \\
\hline Borad et al., 1991 & $1988-89$ and $1989-90$ & Anand, Gujarat & $24-40 \%$ grain damage in 15 genotypes \\
\hline Talekar, 1988 & $1985-86$ & Shanhua, Taiwan & $43 \%$ seed damage \\
\hline Hong et al., 1992 & 1990 & Hanoi, Vietnam & $88-99 \%$ seed damage in 6 cultivars \\
\hline
\end{tabular}

${ }^{1}$ India, unless otherwise noted. 
recorded as parasitoids of $M$. obtusa (Table 4). Most of the studies on $M$. obtusa's natural enemies have focused on three groups of parasitoids: Euderus spp. (Eulophidae), Eurytoma sp. (Eurytomidae) and Ormyrus spp. (Ormyridae). Euderus lividus (Ashmead) (Eulophidae) was the first parasituid of $M$. obtusa reported (Ahmad, 1938). Mani (1939) studied a series reared by Ahmad and noted a wide range in adult size and coloration. Euderus spp. are ectoparasitoids. Females of E. agromyzae Gangrade (Eulophidae) usually deposit one egg per host, although up to five have been observed (Gangrade, 1962) while $E$. lividus females deposit up to nine eggs per host (Ahmad, 1940). It was earlier thought that females oviposited through the exit hole cut by the last instar $M$. obtusa larva. This would restrict these parasitoids to attacking final instar larvae. Singh (1991) however, found that second instars collected from the field had already been parasitized by $E$. lividus. The immature stages of both Euderus spp. last for 25-45 days depending on temperature (Ahmad, 1940; Gangrade, 1962; Singh et al., 1991). Gangrade (1962) and Singh et al. (1991) give detailed accounts of the biology and development of $E$. agromyzae and E. lividus respectively. Euderus spp. are widespread in India, occuring in 10 of the 11 states surveyed, and are the first or second most common parasitoid of $M$. obtusa (Sithanantham et al., 1987). Parasitism rates of more than $25 \%$ have been reported for this group (Ahmad, 1940; Thakur and Odak, 1982). In Sri Lanka, Eudenus sp. is less common, emerging from only $2 \%$ of hosts (Fellowes and Amarasena, 1977). Euderus sp. has also been reared from $M$. obtusa on pigeonpea in the Philippines (Litsinger, pers. commun. in Talekar, 1990).

Both Ormyrus orientalis (Walker) and O. fredricki Narendran (Ormyridae) emerge from pod fly puparia and most authors consider them primary parasitoids, although this has not been confirmed. Singh and Singh (1991) reported $O$. orientalis ovipositing in host pupae while Singh (1991) observed $O$. orientalis attacking third instar larvae. The developmental biology and immature stages have been described by Singh and Singh (1991). Ormynus orientalis is widespread in India but generally $<6 \%$ parasitism is reported (Sithanantham et al., 1983; Sebastian, 1993). Parasitism levels of $12.5 \%$ have been recorded in central India (Thakur and Odak, 1982) and 30\% from Sri Lanka (Fellowes and Amarasena, 1977). Ormyrus fredricki has recently been reported from India, but no information on its biology is available (Peter, 1992).

Eurytoma sp. females oviposit on final instar $M$. obtusa larvae or between the host body and the puparium and emerge from the pupal stage (Singh, 1994). The immature stages are completed in approximately 35 days under laboratory conditions (Singh et al., 1991). This parasitoid is less widespread in India, recorded from 7 of 11 states surveyed, and is of relatively minor importance, occuring in $<2 \%$ of samples in both India and Sri Lanka (Sithanantham et al., 1983; Fellowes and Amarasena, 1977). It has also been reported from the Philippines (Litsinger, pers. commun., in Talekar, 1990).

The other parasitoids of $M$. obtusa have been less well studied. Two Bracon spp. (Braconidae) have been obtained from $M$. obtusa on F macrophylla (Sah and Mehra, 1986) but not on pigeonpea. No information on the biology, ecology or incidence has been reported for Plutarchia. Sithanantham et al. (1987) indicate that Antistrophoplex (Torymidae) may be a hyperparasitoid. The genus Antistrophoplex has been synonomized with the valid genus Microdontomenus (Grissell, pers. commun., 1997). There are no other species of Microdontomerus reported from India and Grissell suggests that the record of Antistrophoplex

Table 4. Parasitoids reared from Melanagromyza obtusa

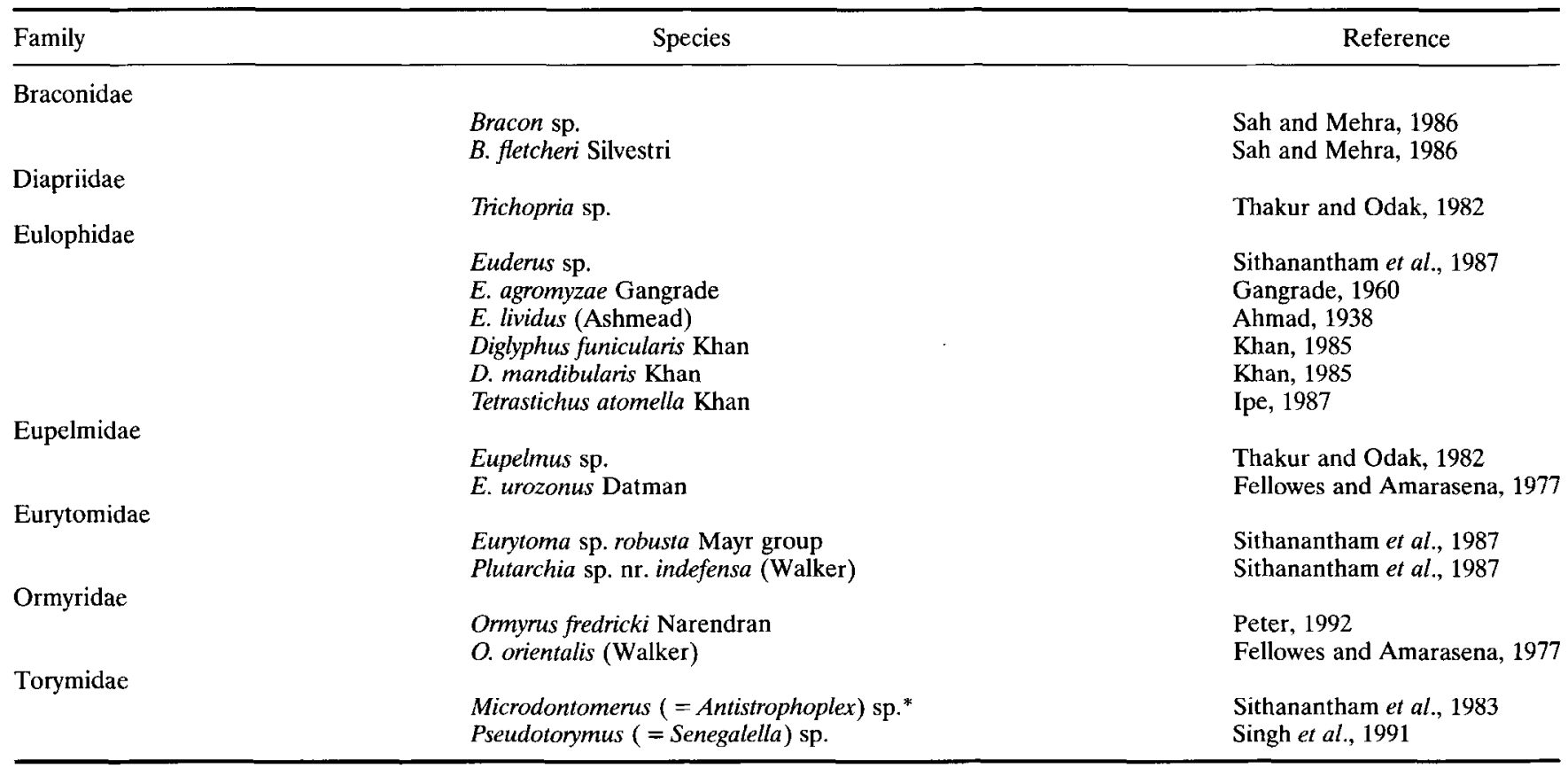

*Possible mis-identification of Pseudotorymus sp. (Grissell, pers. commun., 1997). 
could be a misidentification of a species of Pseudotorymus (Torymidae), a genus reliably known from India. Senegalella sp. is a larval-pupal ecto-parasitoid which attacks third instar $M$. obtusa larvae (Singh, 1994). This genus has recently been synonomized and is now correctly referred to as Pseudotorymus (Torymidae) (Grissell, 1995). The immature stages and adult have becn described by Singh and Manwani (1993). Total immature development time requires 15-35 days (Singh, 1994). Thakur and Odak (1982) reported that Trichopria sp. (Diapriidae), Eupelmus $\mathrm{sp}$, and E. urozonus Datman (Eupelmidae) parasitized $18 \%, 12.5 \%$ and $9.5 \%$, of available hosts in central India, respectively. They provide no information about the size or frequency of samples collected in this study. The high parasitism levels reported for Trichopria sp. are questionable, especially as this parasitoid has not been reported in any other study. Eupelmus urozonus is also present in Sri Lanka, where $2 \%$ parasitism was reported in the only available study (Fellowes and Amarasena, 1977).

The seasonal abundance and/or impact of $M$. obtusa parasitoids may be related to environmental temperatures. Ahmad (1940) observed that E. lividus was rare during the winter and found that its high developmental threshold made it less effective at low temperatures. Singh (1992) reported less activity in December, when temperatures are lower, for three parasitoids on long duration pigeonpea. Other authors have reported parasitism levels of $3-21 \%$ in December in different Indian states (Sebastian, 1993; Sithanantham et al., 1983). Research at ICRISAT over 5 years showed combined parasitism levels of $7-18 \%$ in December, but the mean was only slightly lower than in November and January (Sithanantham et al., 1987).

It is difficult to evaluate the effectiveness of the parasitoids which attack $M$. obtusa because in most reports the number of hosts collected have not been given. Although parasitism levels may reach $50 \%$ by the end of the pigeonpea season (Ahmad, 1940), the guild of parasitoids which attack $M$. obtusa are reportedly not effective in minimizing damage and yield losses. Detailed life-table studies would establish the importance of natural enemies in pod fly population dynamics.

\section{Host-plant resistance}

Host-plant resistance is one of the most important and widely used components in integrated pest management. Pest resistant cultivars, when available, provide a sustainable solution at relatively low cost to a wide variety of farmers. Host-plant resistance has significant advantages over other pest control strategies in situations where:

1. an insect is exposed for only a brief period of its life cycle;

2. the crop is of low economic value;

3. the pest is continuously present and is the single most limiting factor in successful cultivation of a crop in a wide area;
4. other controls are not available (Ortman and Peters, 1980).

These four conditions apply to $M$. obtusa on pigeonpea throughout much of its range.

\section{Host evasion}

Host evasion is one of several phenomena which results in apparent resistance by some genotypes relative to others. Asynchrony between insect pest and host-plant phenologies results in plants or genotypes which escape or avoid peak pest attack and damage. Yadava et al. (1983a) found that the relative time of maturity in pigeonpea greatly influences the quality and quantity of damage by $M$. obtusa. They observed that pigeonpea cultivars which matured at the end of November in India exhibited only $4 \%$ seed damage due to pod fly while cultivars harvested in mid-February suffered $11 \%$ seed damage, and those harvested in the last week of April had 35\% seed damage. Lal et al. (1988) confirmed that in northern India early maturing varieties showed low pod fly damage (13\% seed damage) in comparison to late maturing varieties (27-35\% seed damage). Pigeonpea cultivars which mature early can avoid substantial damage from $M$. obtusa.

The use of determinate versus indeterminate pigeonpea genotypes also acts as a host evasion strategy. Determinate type pigeonpea genotypes suffer less pod fly damage than in indeterminate plant types. Seed damage in a determinate genotype was $9-13 \%$ lower than in an indeterminate genotype of similar duration over a 3 year period (Lal et al., 1986). Gupta et al. (1991), using data from a number of trials conducted over 5 years at Hisar in northern India, reported a similar result. The reason for the higher pod fly damage in the indeterminate genotype was because of the continuous availability of immature pods, the preferred stage for pod fly oviposition and development, in these genotypes (Lal et al., 1986). The relatively high levels of natural out-crossing in pigeonpea has produced a mixture of highly heterogeneous, asynchronous and indeterminate plant types in farmers fields, particularly in medium- and long-duration genotypes (Laxman Singh et al., 1990). The consequence of this is an extended reproductive phase with immature pods being available for as long as 4 months, allowing many generations of pod fly to develop resulting in high populations (DPR, 1987). Unpublished results from the Indian Institute of Pulses Research (IIPR) suggest that by synchronizing and restricting the reproductive phase of pigeonpea, damage from pod fly can be reduced.

\section{Genetic resistance}

Pigeonpea is a self-pollinated crop, although outcrossing is common (Bhatia et al., 1981; Prasad et al., 1972). Segregation therefore has been a major hurdle to incorporating resistance into preferred plant types. The identification and development of promising and 
reliable sources of resistance to pod fly in pigeonpea has progressed by advancing single plant selections for 5-7 years (Dias et al., 1981; Reed and Lateef, 1990). Much of this work has been conducted over the past 20 years at ICRISAT, IIPR and collaborating centers of the All India Coordinated Pulse Improvement Project (AICPIP).

Evaluation of pigeonpea germplasm for reduced susceptibility to pod fly was initiated at ICRISAT in 1975 (Davies and Lateef, 1978; Lateef, 1977). A methodology for open field screening was developed in which material was compared with check cultivars of similar maturity under pesticide free conditions. Promising selections were advanced through selfed seeds for up to 4 years in replicated trials. In these trials selections are grouped into narrow maturity ranges and evaluated under sprayed and unsprayed conditions (Lateef and Reed, 1981; Reed and Lateef, 1990). The large plant size ( $2 \mathrm{~m}$ and above), long growing season (140-300 days), ability to compensate for damage with multiple flushes of flowers and high incidence of out-crossing have all posed problems and slowed progress. A method of grading test materials based on pod damage relative to standard controls and converted to a scale of 1-9 was developed to deal with the problem of seasonal and yearly variations in the intensity of infestations and confusing relative performance across localities and years (Lateef and Reed, 1985).

ICRISAT screened more than 10,000 germplasm accessions and breeding lines for resistance to $M$. obtusa under pesticide-free open field plots over a period of 6-11 years per selection (Lateef and Pimbert, 1990). Several lines, including material in short, medium and long duration maturity groups, have shown consistent resistance to $M$. obtusa (Table 5). Some of this material has also been evaluated in multi-location trials in the Indian national programme through the AICPIP network (Table 6). The Indian Institute of Pulses Research (IIPR) has worked extensively on host plant resistance to pod fly in medium- and long-duration pigeonpea. After identifying tolerant/resistant single plant selections, progeny were advanced through selfed seeds for 6-8 years. In addition, more than 3000 lines were screened between 1978 and 1990 and another 2033 pigeonpea accessions were screened from 1991 to 1994. Among the latter, $8.3 \%$ suffered less than 5\% pod damage and were considered promising for further evaluation. Ten pigeonpea selections (ICRISAT 16, 166-2-1, ICP 7946-1-3-3, ICP 127, SL 12-3-1, 41-3-3, PDA 88-2E-3-1, ICP 3401, ICP 7950 and ICP 12304) were identified as highly promising after extensive testing (Lal, 1996). Many of these selections have been evaluated in multi-location and multi-year testing through the AICPIP network and have shown stable and consistent performance (Tables 6 and 7). Two selections, PDA 88-2E and PDA 89-2E, have been used as donors in the pod fly resistance breeding programme (Lal, 1996).

The genus Cajanus has been reorganized to incorporate the genus Atylosia (van der Maesen, 1985). One wild species, $C$. scarabaeoides (formerly $A$. scarabaeoides), is considered highly resistant to $M$. obtus $a$
Table 5. Pigeonpea genotypes with resistance to pod fly, Melanagromyza obtusa, ICRISAT Asia Center, 1979-91

\begin{tabular}{llc}
\hline Genotype & $\begin{array}{c}\text { Mean resistance } \\
\text { rating }^{2}\end{array}$ & $\begin{array}{c}\text { Range of pod } \\
\text { fly damage (\%) }\end{array}$ \\
\hline Short duration & & \\
ICP 909-E3 & $4.2(11)^{3}$ & $1-25$ \\
Control (T-21) & $6.0(11)$ & $1-15$ \\
Medium duration & & \\
ICP 7050-E1 & $2.6(7)$ & $1-14$ \\
ICP 10531-E1 & $3.8(11)$ & $1-26$ \\
ICP 7941-E1 & $3.7(9)$ & $2-22$ \\
ICP 7946-E1 & $3.6(11)$ & $2-14$ \\
ICP 6977-E1 & $3.5(6)$ & $1-22$ \\
ICP 7194-S4 & $4.2(9)$ & $3-24$ \\
Controls & & \\
BDN 1 & $6.0(10)$ & $1-31$ \\
C 11 & $6.0(11)$ & $3-30$ \\
Long duration & & $7-27$ \\
ICP 8102-5-S1 & $5.3(11)$ & $11-30$ \\
ICP 8094-2-S2 & $5.3(11)$ & $6-23$ \\
ICP 7176-5 & $4.6(11)$ & 34 \\
Controls & & $13-32$ \\
Bahar & $6.0(2)$ & $17-44$ \\
ICP 6443 & $6.0(11)$ & \\
PPE 36-2 & $7.7(7)$ & \\
\hline
\end{tabular}

'Source: ICRISAT, 1991.

2Relative resistance rating in comparison with controls scored on a scale of $1-9$, where $1=$ resistant, $9=$ susceptible.

${ }^{3}$ Figures in parentheses indicate number of years tested.

(Saxena et al., 1990). Observations over 5 years at ICRISAT-Patancheru revealed that $<1 \%$ of $C$. scarabaeoides pods were infested by $M$. obtusa (Crop Protection Division, unpublished data). Although this wild species appears to be a good source of resistance there is little knowledge of the mechanism of resistance and there have been no attempts to transfer resistance to pigeonpea. Reed and Lateef (1990) considered this approach to be less productivc than searching for resistance within the $C$. cajan germplasm.

Table 6. Results of multilocation evaluation of pigeonpea genotypes with resistance to pod fly, Melanagromyza obtusa, by the All India Coordinated Pulses Improvement Project (AICPIP), $1988-95^{1}$

\begin{tabular}{lcr}
\hline Gcnotypc & $\begin{array}{c}\text { Mcan resistance } \\
\text { rating }\end{array}$ & $\begin{array}{r}\text { Range of pod } \\
\text { fly damage (\%) }\end{array}$ \\
\hline PDA 92-3E & $3.7(5 / 4)^{3}$ & $5.8-37.0$ \\
PDA 89-2E & $3.7(5 / 5)$ & $4.8-37.5$ \\
PDA 92-1E & $5.0(5 / 2)$ & $6.6-54.0$ \\
PDA 92-2E & $4.0(5 / 3)$ & $8.1-49.7$ \\
PDA 88-2E & $3.5(6 / 5)$ & $3.0-37.7$ \\
PDA 93-2E & $4.4(5 / 5)$ & $14.2-42.3$ \\
PDA 88-1E & $4.0(4 / 4)$ & $8.9-39.0$ \\
PDA 93-1E & $4.4(2 / 2)$ & $27.7-44.3$ \\
PDA 91-2E & $5.5(2 / 1)$ & $12.7-21.3$ \\
PDA 88-3E & $4.4(3 / 3)$ & $13.9-37.0$ \\
PDA 89-3E & $3.8(3 / 3)$ & $8.0-28.5$ \\
Bahar (Ch.) & $5.8(6 / 6)$ & $12.9-64.0$ \\
NP(WR)-15 & $5.0(5 / 5)$ & $8.5-53.8$ \\
MA-2 & $4.6(4 / 6)$ & $11.5-40.3$ \\
\hline
\end{tabular}

1Source: AICPIP Annual Reports (1988-89 to 1994-95).

${ }^{2}$ Relative resistance rating in comparison with controls scored on a scale of $1-9$, where 1 = resistant, 9 = susceptible.

${ }^{3}$ Figures in parentheses indicate number of locations and years tested. 
Table 7. Per cent pod damage due to Melanagromyza obtusa and relative resistance rating of nine pigeonpea genotypes at four locations in India, 1994/95 ${ }^{1}$

\begin{tabular}{|c|c|c|c|c|c|}
\hline Genotype & ICRIS $\Lambda T^{2}$ & BHU & IIPR & NDUAT & Mean \\
\hline SL 21-1-3 & $5.5(2)^{3}$ & $17.9(3)$ & $11.7(2)$ & $1.5(2)$ & $9.15(2.25)$ \\
\hline SL 22-2-3 & $1.0(2)$ & $2.6(2)$ & $3.5(2)$ & $2.0(2)$ & $2.27(2.00)$ \\
\hline SL 21-9-3 & $1.7(2)$ & $4.9(2)$ & $5.0(2)$ & $0.0(1)$ & $2.90(1.75)$ \\
\hline SL 21-6-2 & $4.8(2)$ & $16.5(3)$ & $13.0(2)$ & $1.5(2)$ & $3.95(2.25)$ \\
\hline SL 12-3-1 & $1.5(2)$ & $5.2(2)$ & $4.0(2)$ & $2.0(2)$ & $3.17(2.00)$ \\
\hline PDA $88-2 E$ & $3.0(2)$ & $7.2(2)$ & $9.3(2)$ & $2.0(2)$ & $5.37(2.00)$ \\
\hline PDA 89-2E & $3.5(2)$ & $6.8(2)$ & $8.9(2)$ & $1.0(2)$ & $5.05(2.00)$ \\
\hline PDA 92-3E & $4.1(2)$ & $14.2(3)$ & $11.8(2)$ & $2.0(2)$ & $5.03(2.25)$ \\
\hline PDA 93-1E & $6.3(2)$ & $7.7(3)$ & $17.6(3)$ & $0.0(1)$ & $7.90(2.25)$ \\
\hline \multicolumn{6}{|l|}{ Controls } \\
\hline Bahar & $17.7(4)$ & $34.5(5)$ & $49.8(5)$ & $21.0(6)$ & $38.80(5.00)$ \\
\hline $\mathrm{T}-7$ & $27.8(6)$ & $42.4(6)$ & $58.5(6)$ & $13.0(4)$ & $33.42(5.50)$ \\
\hline
\end{tabular}

Source: Lal, 1996.

¿Locations: ICRISAT Asia Center, Patancheru, Andhra Pradesh; BHU = Banares Hindu University, Varanasi, Uttar Pradesh; IIPR = Indian Insitute of Pulses Research, Kanpur, Uttar Pradesh; NDUAT = Narender Dev University of Agriculture and Technology, Faizabad, Uttar Pradesh.

${ }^{3}$ Figure in parentheses are relative resistance ratings in comparison with controls scored on a scale of $1-9$, where $1=$ resistant, $9=$ susceptible.

\section{Mechanisms of resistance}

Both ovipositional non-preference and antibiosis have been suggested as modes of resistance for $M$. obtusa (Reed and Lateef, 1990). Several plant characters have been implicated in pod fly ovipositional preference including pod trichomes, the concentrations of tannin-like substances beneath the outer epidermis, and the thickness of the fibrous cell layer above the inner epidermis (Sithanantham et al., 1981). Lal and Yadava (1994) observed that resistant pigeonpea selections had fewer pod fly eggs than susceptible selections, indicating that ovipositional nonpreference may be an important character in pod fly resistance.

As noted earlier a positive correlation between seed damage and both pod width and pod length has been observed in several studies (Lal et al., 1988; Thakur et al., 1989; Veda et al., 1975). Lal et al. (1988) also noted that black- or brown mottled seeds showed lower pod fly damage $(4.2-4.3 \%)$ than white or yellow seeds $(20.6-23.5 \%)$. Similarly, sickle shaped pods with deep constrictions between seed locules were less preferred for pod fly oviposition than cultivars with shallow constrictions. The conclusion drawn from these studies is that cultivars with small pods, small, dark-coloured seeds and deep constrictions between locules would be less preferred by $M$. obtusa females and would suffer less pod fly damage. It has not been reported whether a pigeonpea cultivar with these characteristics would be acceptable to farmers.

Dass and Odak (1987) reported correlations between several biochemical characters of pigeonpea pod walls and damage by $M$. obtusa. Among the relationships they observed were negative correlations between the amount of wax, phenols, total amino acids, proline, crude fibres and ascorbic acid and pod fly incidence. They also reported a positive correlation between the amount of nitrogen and pod fly infestation. An unpublished study at IIPR compared some biochemical constituents in the pods of a resistant and a susceptible pigeonpea genotype. The resistant genotype had higher levels of phenols, triacontane and hentriacontane compared to the susceptible genotype. It is not know whether these differences are consistent among the large number of resistant genotypes which have been identified and what the role of these compounds is in resistance to pod fly.

\section{Inheritance}

Little information on the genetics and inheritance of resistance to $M$. obtusa in pigeonpea is available. The following preliminary evidence, reported by Lal (1996), indicates that inheritance of resistance appears to be additive. Studies on the general combining ability of selected pigeonpea genotypes has shown that genotypes PDA 89-5E, PDA 88-2E and PDA $89-7 \mathrm{E}$, which are highly resistant to $M$. obtusa, should produce the most promising and desirable segregants. The specific combining ability represents the dominance and epistatic effects which are nonfixable in nature. Seven out of 15 crosses made in 1992-1993 (Bahar $\times$ PDA 89-5E, Bahar $\times$ BDA 88-2E, Bahar $\times$ PDA $89-7 \mathrm{E}, \quad$ T-7 $\times$ PDA $89-5 \mathrm{E}$, T-7 $\times$ PDA $88-2 \mathrm{E}, \quad \mathrm{T}-7 \times$ PDA $89-7 \mathrm{E}$ and PDA $89-5 \mathrm{E} \times$ PDA $88-2 \mathrm{E}$ ) were good specific combiners for pod fly resistance.

The estimates of general combining ability effects were negative and significant for PDA $88-2 \mathrm{E}$ and PDA $89-2 \mathrm{E}$ for pod fly, and thus were expected to offer the most promise in breeding for useful and desirable segregants. Nine of 27 crosses evaluated during 1993-1994 (Bahar $\times$ DPPA 85-15, Bahar $\times$ PDA $88-2 \mathrm{E}$, Bahar $\times$ PDA $89-2 \mathrm{E}$, DPPA $8515 \times$ ICP 8860 , DPPA $85-15 \times$ NP (WR) 15 , ICP $8860 \times$ PDA 88-2E, KPBR 80-2-1 $\times$ PDA 88-2E, KPBR 80-2-1 $\times$ PDA $89-2 \mathrm{E}$ and NP (WR) $15 \times$ PDA $88-2 \mathrm{E}$ ) were found to be good specific combiners for pod fly resistance.

\section{Cultural control}

Several cultural control practices have been investigated for their effect either in modifying pod fly 
population levels or in reducing pod fly damage. Veeraswamy (1959) was the first to study the effect of sowing time on pod fly damage. In a 1 year trial, grain damage was five times lower when the crop was sown 6 weeks earlier than normal. More recently, sowing time was shown to have no effect on $M$. obtusa damage in a 2-year study in Gujarat (Kabaria et al., 1990). Differences in pod damage were noted among genotypes but this was not associated with sowing time. Yadav et al. (1992) reported 50\% less pod and grain damage when pigeonpea was sown 5 weeks early relative to normal sowing time in a 2-year study.

Intercropping with blackgram [Vigna mungo (L.) Hepper], mung bean ( $V$ radiata), cowpea ( $V$. unguiculata), sorghum [Sorghum bicolor (L.) Moench] or pearl millet [Pennisetum glaucum (L.) R.Br.] did not significantly reduce the incidence of $M$. obtusa relative to a pigeonpea monocrop (Singh and Singh, 1978). A 2-year study showed a consistent trend of lower levels of seed damage by $M$. obtusa in three short duration pigeonpea cultivars intercropped with mung bean than in monocropped pigeonpea plots (Dahiya and Chauhan, 1992). Yadav et al. (1992) also observed a lower incidence of $M$. obtusa and less grain damage when pigeonpea was intercropped with mung bean relative to sole pigeonpea. Plot size in both of these experiments was very small $\left(\leq 10 \mathrm{~m}^{2}\right)$ and it is questionable whether a mobile insect would recognize inter-plot differences at such a small scale. Large plot evaluations are needed to confirm the benefit of reduced pod fly damage in pigeonpea by intercropping with mung bean.

The effect of fertilizer and intercultivation operations on pod fly were studied by Badaya et al. (1990). They found that the recommended fertilizer dose (18 kg $\mathrm{N}_{2}+46 \mathrm{~kg} \mathrm{P}_{2} \mathrm{O}_{5} \mathrm{ha}^{-1}$ ) and two hand weedings + one interrow cultivation both singly and in combination, resulted in significantly less grain damage due to podfly than the control. Yadav et al. (1992) noted small and inconsistent differences in the effect of phosphorus fertilizer on $M$. obtusa incidence and damage.

\section{Chemical control}

There is a voluminous and often confusing array of reports on chemical control of $M$. obtusa in pigeonpea. A wide range of chemical insecticides has been tested, most frequently as liquid formulations. All of the insecticides which have been evaluated have been found to reduce grain damage and/or increase yields relative to untreated control plots in one or more studies. The first insecticides were tested in the early 1960s and included BHC, DDT, dipterex, endrin, parathion, dieldrin and methyl demeton. Among these DDT, dipterex and endrin provided the best control (David, 1964; Srivastava and Srivastava, 1966). More recently organophosphate, carbamate and synthetic pyrethroid insecticides have been evaluated for pod fly control. The insecticides most frequently reported as providing effective control against pod fly in pigeonpea are endosulfan, quin- alphos, monocrotophos, dimethoate, methamidophos, fenavalerate, cypermethrin and decamethrin (Bhalani and Parsana, 1991; Lal and Yadava, 1988; Patil et al., 1990; Prasad and Singh, 1992; Sahu et al., 1991; Singh et al., 1988; Sontakke and Mishra, 1991).

Several formulations of neem (Azadiracha indica A. Juss.) extracts and karanj [Pongamia pinnata (L.)] oil have been evaluated for control of pod fly. Five and eight per cent neem seed kernel extracts (Dhanorkar and Daware, 1979; Pandao et al., 1993; Srivastava et al., 1984; Thakre et al., 1981), 2\% ethanolic extract of neem seed kernels and $10 \%$ neem oil (Singh et al., 1985) treatments resulted in less pod fly damage and/or higher yields than untreated control treatments. Many commercial formulations of azadiractin are now available and this may increase interest in using neem to control pod fly. Two per cent karanj oil (Sundara Babu and Rajasekaran, 1984) and $0.2 \%$ karanj oil $+1 \%$ soap (Degaonkar et al., 1988) were also found to be effective in reducing levels of pod fly damage relative to untreated control plots.

Because the immature stages of the pod fly are concealed within the pigeonpea pod, systemic insecticides provide more effective control than contact insecticides. Several systemic insecticides, including thiometon and formothion, have produced high levels of egg and larval mortality in field tests (Singh et al., 1984). Lal and Yadava (1988) compared the effectiveness of granular systemic insecticides applied at planting with foliar applications at podding stage. They found that two applications of $0.05 \%$ dimethoate gave better control than soil applications of carbofuran, disulfoton and phorate at planting, although all treatments suffered less damage than control plots. Melanagromyza obtusa altacks pigeonpea in the reproductive phase (40 or more days after sowing) and it is unlikely that the effect of the soil applied systemic insecticides remain for more than 30 days after application.

Several studies have shown that two and three applications are more effective in reducing pod fly infestations than single applications of the same insecticide (Bhadauria et al., 1991; Singh and Rai, 1985; Sinha and Srivastava, 1989). Typical of these reports is the data presented by Yadava et al. (1983b) who reported $14 \%$ grain damage in untreated plots, $7 \%$ damage with one, $5 \%$ damage with two and $3 \%$ damage with three sprays of monocrotophos $(0.04 \%)$. The superior performance of two and three sprays is due partly to the 'calendar spray' approach which is used to time insecticide applications in pigeonpea. The first application is made at the flowering stage and the second and third sprays are applied 1 and 2 weeks later. Melanagromyza obtusa prefers to oviposit in tender green pods and pesticide application timed to coincide with this stage will be more effective than sprays at either earlier or later stages (Bhadauria et al., 1991).

The current control recommendations for $M$. obtusa on pigeonpea in India are three sprays of monocrotophos $36 \mathrm{EC} \quad 0.04 \%$, endosulfan $35 \mathrm{EC}$ $0.07 \%$ or ekalux $25 \mathrm{EC} 0.05 \%$, all applied at $500-1000$ water ha ${ }^{-1}$. The first application is made at 
pod initiation stage and the second and third sprays at 10-day intervals (Sachan, 1995). There has been no report of insecticide resistance in $M$. obtusa but this has not been investigated. The impact of chemical pesticides on natural enemies and their interaction with host-plant resistance has also not been investigated.

\section{Future research needs}

Research over the past 50 years has provided a good understanding of the biology, ecology and management of $M$. obtusa. There are however, several areas in which further research is needed. Detailed studies of pod fly population dynamics, including the role of alternate host plants and interactions with natural enemies, are lacking. These studies will clarify the seasonal dynamics of pod fly populations and provide a better understanding of the influence of natural enemies in regulating population fluctuations. These studies will also answer questions about whether $M$. obtusa uses diapause or aestivation to survive the dry season.

The potential for developing pigeonpea cultivars with high levels of resistance to pod fly appears to be good. Several genotypes within the pigeonpea germplasm have already been identified. It would be useful to identify the mechanisms which provide resistance to $M$. obtusa so that pigeonpea and wild species germplasm could be utilized more effectively. The resistant genotypes need to be combined with high yield and consumer-preferred agronomic characteristics before they will be accepted by farmers. The identification of resistance mechanisms and the development of resistant pigeonpea cultivars would be greatly enhanced by techniques to artificially rear $M$. obtusa. This would permit rapid evaluation of specific mechanisms under controlled conditions.

Two other management strategies, intercropping and insecticides, have shown promise in research station trials. Intercropping pigeonpea with mung bean needs to be tested in large plots to verify its efficacy before this strategy can be recommended to farmers. The economics of chemical control should be calculated and a simple but effective set of recommendations developed. The longer term goal of pigeonpea entomologists must be to improve hostplant resistance and the effectiveness of pod fly natural enemies in order to make pesticide application unnecessary.

\section{Acknowledgements}

We thank J, Romeis [International Crops Research Institute for the Semi-Arid Tropics (ICRISAT)] for comments on earlier drafts of this manuscript. Approved as Journal Article No. JA 2058 by International Crops Research Institute for the Semi-Arid Tropics, Patancheru, Andhra Pradesh, India.

\section{References}

Abraham, E. V., Thirumurthi, S., Asaf Ali, K. and Subramaniam, T. R. (1973) Some new pests of sesamum. Madras Agricultural Journal 60, 593

Ahmad, M. (1982) Infection of the pod fly, Melanagromyza obtusa (Mall.) in different varieties of pigeonpea (Cajanus cajan). Pakistan Entomologist 4, 17-20

Ahmad, T. (1938) The tur-pod fly, Agromyza obtusa Mall., a pest of Cajanus cajan. Indian Journal of Agricultural Science 8, 63-76

Ahmad, T. (1940) On the biology of Euderus lividus (Ashm.), a parasite of Agromyza obtusa Mall. Indian Journal of Entomology 2, $59-64$

AICPIP (All India Coordinated Pulse Improvement Project) (1988-1989 to 1994-1995) Entomology - Consolidated Report on Kharif Pulses. All-India Co-ordinated Puises Improvement Project, Indian Institute of Pulses Research, Kanpur 208024 , Uttar Pradesh, India, Indian Council of Agricultural Research. (Limited distribution)

Badaya, A. K., Das, S. B., Thakur, N. S., Shaw, S. S. and Bhalla, P. L. (1990) Effect of interculture operations, fertilizer application and plant protection measures on the incidence of borer complex on pigeonpea. Indian Journal of Plant Protection 18, 27-30

Bhadauria, N. S., Jakhmola, S. S., Bhadauria, S. B. S. and Dhamdhere, S. V. (1991) Effect of time of application of insecticide for control of pigeonpea pod-fly (Melanagromyza obtusa) in pigeonpea (Cajanus cajan). Indian Joumal of Agricultural Science 61, 345-347

Bhalani, P. A. and Parsana, G. J. (1991) Estimation of losses due to podfly, Melanagromyza obtusa Malloch in pigeonpea under Junagadh (Gujarat) condition. Gujarat Agricultural University Research Journal 17, 49-53

Bhalani, P. A. and Parsana, G. J. (1992) Field studies for varietal resistance in pigeonpea to podlly, Melanagromyza obtusa Mall. Gujarat Agricultural University Research Journal 17, 168-171

Bhatia, G. K., Gupta, S. C., Green, J. M. and Sharma, D. (1981) Estimates of natural cross pollination in Cajanus cajan (L.) Millsp.: Several experimental approaches. In: Proceedings of the International Workshop on Pigeonpeas, Vol. 2, pp. 129-136. Patancheru, Andhra Pradesh, India

Bhosale, D. J. and Nawale, R. N. (1985) Field screening of pigeonpea germplasm against podfly Melanagromyza obtusa (Malloch). Indian Journal of Entomology 47, 92-97

Bindra, O. S. and Jokhmola, S. S. (1967) Incidence of and losses caused by some pod-infesting insects in different varieties of pigeon-pea Cajanus cajan (L.) Millsp.. Indian Journal of Agricultural Science 37, 177-186

Bindra, O. S. and Singh, H. (1972) Tur pod fly, Melanagromyza obtusa Malloch (Diptera: Agromyzidae). Pesticides 6, 7 11-12

Borad, P. K., Patel, J. R. and Patel, M. G. (1991) Evaluation of vegetable pigeonpea (Cajanus cajan) genotypes resistant to grampodborer (Helicoverpa armigera), plume moth (Marasmarcha liophanes) and podfly (Melanagromyza obtusa). Indian Journal of Agricultural Science 61, 682-684

Dahiya, K. K. and Chauhan, R. (1992) Management of podfly Melanagromyza obiusa Millsp. [sic] damage in pigeonped through intercropping. In Bioecology and Control of Insect Pests Proceedings of the National Symposium on Growth, Development and Control of Insect Pest, ed. S. C. Goel, pp. 232-235. Uttar Pradesh Zoological Society, Muzaffarnagar, Uttar Pradesh 251 001, India

Dass, S. B. and Odak, S. C. (1987) Biochemical basis of resistance in pigeonpea pod walls to podfly Melanagromyza obtusa Malloch (Diptura: Agromyzidae). Crop Improvement 14, 64-68

David, B. V. and Janagarajan, A. (1969) Notes on pests of safflower in Tamil Nadu. Madras Agricultural Journal 56, 534-538

David, K. S. (1964) A note on Heliothis armigera and Agromyza obtusa M. affecting red gram pods and their control. Madras Agricultural Journal 51, 90 
Davies, J. C. and Lateef, S. S. (1978) Recent trends in grain legume pest research in India. In Pests of Grain Legumes: Ecology and Control, ed. S. R. Singh, H. F. van Emden and T. A. Taylor, pp. 25-31. Academic Press, London

Degaonkar, A. M., Kurtadikar, J. S. and Rekawar, B. V. (1988) Economical control measures against arhar pod borer complex in Marathwada region. Pesticides 22(8), 15-16, 27

Dias, C. A. R., Lal, S. S. and Yadav, C. P. (1981) Relative susceptibility of pigeonpea cultivars against podfly Melanagromyza obtusa Malloch under field conditions. In Proceedings of the International Workshop on Pigeonpeas, Vol. 2, pp. 337-340. Patancheru, Andhra Pradesh, India

Dhanorkar, B. K. and Daware, D. G. (1979) Evaluation of some insecticides for the control of podborers on redgram. Research Bulletin of Marathwada Agricultural University 3, 85-86

DPR (Directorate of Pulses Research) (1987) Annual report, Indian Council of Agricultural Research. (Limited distribution)

Fellowes, R. W. and Amarasena, J. (1977) Natural parasites of some major grain legume pests in the dry zone. Tropical Agriculturist 133, 83-89

Gangrade, G. A. (1960) Description of a new species of the genus Euderus Haliday, 1844 (Eulophidae: Chalcidoidea). Indian Joumal of Entomology 22, 80-82

Gangrade, G. A. (1962) The biology and morphology of immature stages of Euderus agromyzae Gangrade (Eulophidae: Hymenoptera). Indian Journal of Entomology 24, 265-273

Gangrade, G. A. (1963) Assessment of damage to Tur Cajanus cajan in Madhya Pradesh by the tur-pod fly, Agromyza obtusa Malloch. Indian Journal of Agricultural Science 33, 17-20

Gangrade, G. A. (1965) Losses to tur (Cajanus cajan) by Melanagromyza obtusa Malloch. Indian Journal of Entomology 26, 364-365

Gupta, S. C., Lateef, S. S. and Ariyanayagam, R. P. (1991) Are determinates inferior to indeterminates in short-duration pigeonpea?. International Pigeonpea Newsletter 13, 11-13

Grissell, E. E. (1995) Toryminae (Hymenoptera: Chalcidoidea: Torymidae): a Redefinition, Generic Classification, and Annotated World Catalog of Species. Associated Publishers, Gainesville, FL

Hong, N. X., Nam, N. H. and Tuong, L. K. (1992) First survey of pigeonpea insect pests in Vietnam. International Pigeonpea Newsletler 15, 30-31

Husain, M. and Khan, M. Q. (1965) Melanagromyza obtusa (Malloch) - A potent pest of safflower in Andhra Pradesh. Indian Oilseeds Journal 9, 317-322

ICRISAT (International Crops Research Institute for the SemiArid Tropics). (1982) Annual Report 1981. Patancheru, Andhra Pradesh, India

ICKISA' (International Crops Research Institute for the SemiArid Tropics). (1984) Pulse Entomology (Pigeonpea) Report of Work June 1983-May 1984, Department Progress Report 14, Patancheru, Andhra Pradesh, India

ICRISAT (International Crops Research Institute for the SemiArid Tropics). (1986) Annual Report 1985. Patancheru, Andhra Pradesh, India

ICRIS $\Lambda T$ (International Crops Research Institute for the SemiArid Tropics). (1991) Legumes Program Annual Report 1990 Patancheru, Andhra Pradesh, India

Ipe, I. M. (1974) Morphological, behavioral and biological studies of Melanagromyza obtusa (Malloch) (Diptera: Agromyzidae) on Cajanus indicus Spreng. Zeitschrift für Angewandte. Fntomologie 75, 89-98

Ipe, 1. M. (1987) Biosystematic studies on Agromyzidae from India. Proceedings of the Indian Academy of Sciences (Animal Sciences) 96, 573-581.

Jadhav, L. D., Nawale, R. N. and Ajri, D. S. (1983) Observations on the reaction of some Atylosia sp. to pigeonpea pod borer complex. Journal of the Maharashtra Agricultural Universities 8, $287-288$
Kabaria, B. B., Goyal, S. N., Jose, V. T. and Shah, A. H. (1990) Effect of sowing time and varieties on major insect pests and grain yield of pigeonpea in Gujarat India. Intemational Pigeonpea Newsletter 11, 18-21

Kabaria, B., Goyal, S. N. and Shah, A. H. (1988) Surveillance of insect pests damage to pigeonpea at podding stage in Bharuch district Gujarat, India. International Pigeonpea Newsletter 8, 15-16

Kabir, A. K. M. F. (1978) Pests of grain legumes and their control in Bangladesh. In Pests of Grain Leyumes: Ecology and Control, ed. S. R. Singh, H. F. van Emden and T. A. Taylor, pp. 3-36. Academic Press, London

Kaushik, S. K., Chaudhary, J. P. and Khokhar, K. S. (1988) Pattern of population distribution of tur pod fly, within pigeonpea plant. Indian Joumal of Ecology 15, 159-162

Khan, M.A. (1985) Eulophid parasites (Hymenoptera: Eulophidae) of Agromyzidae in India. Joumal of the Bombay Natural History Society 82, 149-159

Khokhar, K. S., Singh, Z. and Sucheta (1987) Carry-over of Melanagromyza obtusa (Malloch) (Diptera: Agromyzidae) during off-season on a legume weed and its seasonal activity. Indian Journal of Agricultural Science 57, 214-215

Kulkarni, S. M. (1966) Infestation, sex-ratio and damage by Melanagromyza obtusa (Diptera: Agromyzidae) to Moghania macrophylla seeds in the field. Entomologia Experimentalis et Applicata $9,323-326$

Lal, S. S. (1996) Suppression of podfly, Melanagromyza obtusa Malloch damage in pigeonpea through varietal resistance. Division of Entomology, Indian Institute of Pulses Research, Kanpur, Uttar Pradesh, India. (Limited distribution.)

Lal, S. S. and Yadava, C. P. (1987) Estimate of crop losses in pigeon pea caused by pod borer complex. FAO Plant Protection Bulletin 35, 93-98

Lal, S. S. and Yadava, C. P. (1988) Efficacy of certain insecticides against pod borers infesting pigeonpea. Pesticides 22, 12 30-35

Lal, S. S. and Yadava, C. P. (1994) Oviposition response of podfly (Melanagromyza obtusa) on resistant pigeonpea (Cajanus cajan) selections. Indian Journal of Agricultural Science 64, 658-660

Lal, S. S., Yadava, C. P. and Chandra, S. (1986) Suppression of podfly damage through varietal selection. International Pigeonpea Newsletter 5, 42-43

Lal, S. S., Yadava, C. P. and Dias, C. A. R. (1981) Major pest problems of pigeonpea in Uttar Pradesh India. International Pigeonpea Newsletter 1, 30-31

Lal, S. S., Yadava, C. P. and Sachan, J. N. (1988) Studies on some aspects of oviposition and damage of podfly in relation to the host phenology, Indian Journal of Pulses Research 1, 83-88

Lal, S. S., Yadava, C. P. and Sachan, J. N. (1992) Assessment of pod borers damage on pigeonpea in different agroecological zones of Uttar Pradesh. Indian Journal of Pulses Research 5, 174-178

Lateef, S. S. (1977) Pest control strategy in the semi-arid tropics with special reference to pigeonpea (Cajanus cajan Millsp.) and chickpea (Cicer arietinum L.). In Chemicalisation of Plant Protection in the Tropics and Sub-tropics, Vol. 3, pp. 108-116. Karl Marx University, Leipzig

Lateef, S. S. and Pimbert, M. P. (1990) The search for host plant resistance to Helicoverpa armigera in chickpea and pigeonpea at ICRISAT. In Summary Proceedings of the First Consultative Group Meeting on Host Selection Behaviour of Heliothis armigera, pp. 14-18. ICRISAT, Patancheru, Andhra Pradesh, India

Lateef, S. S. and Reed, W. (1981) Development of a methodology for open-field screening for insect pest resistance in pigeonpea. In Proceedings of the International Workshop on Pigeonpeas, Vol. 2, pp. 315-322. Patancheru, Andhra Pradesh, India

Lateef, S. S. and Reed, W. (1983) Review of crop losses caused by insect pests in pigeonpea internationally and in India. Indian Journal of Entomology, Special Issue 2, 284-293

Lateef, S. S. and Reed, W. (1985) A suggested system of rating pigeonpea and chickpea for field resistance to Heliothis armigera. 
In Proceedings of the National Seminar on Breeding Crop Plants for Resistance to Pests and Diseases, pp. 127-129. Tamil Nadu Agricultural University, Coimbatore, Tamil Nadu, India

Lateef, S. S. and Reed, W. (1990) Insect pests on pigeonpea. In Insect Pests of Tropical Food Legumes, ed. S. R. Singh, pp. 193-242. John Wiley and Sons, New York

Laxman Singh, Gupta, S. C. and Farris, D. G. 1990. Pigeonpea breeding. In The Pigeonpea, ed. Y. L. Nene, S. D. Hall and V. K. Sheila, pp. 375-399. CAB International, Wallingford

Le Pelley, R. H. (1959) Agricultural Insects of East Africa, East Africa High Commission, Nairobi, Kenya

van der Maesen, L. J. G. (1985) Cajanus DC. and Atylosia W. and A. (I Leguminnsae). Agricultural I Iniversity of Wageningen Papers $85-4,1-225$

Malloch, J. R. (1914) Formosan Agromyzidae. Annales HistoricoNaturales Musei Nationalis Hungarici 12, 306-336

Mani, M. S. (1939) Descriptions of new and records of some known chalcidoid and other hymenopterous parasites from India. Indian Journal of Entomology 1, 69-99

Maxwell-Lefroy, H. (1906) Indian Insect Life. Reprinted in 1971, Today and Tomorrow Printers and Publishers, New Delhi

Mehrotra, P., Singh, S. D. and Kaul, C. K. (1989) A note on the chemical control of Melanagromyza obtusa Malloch on cowpea. Indian Joumal of Entomology 5, 355-356

Minja, E. M., Shanower, T. G., Songa, J. M., Ong'aro, J. M., Mviha, P.. Myaka, F. A. and Okurut-Akol, H. (1996) Pigeonpea seed damage from insect pests on farmers' fields in Kenya, Malawi, Tanzania and Uganda. International Chickpea and Pigeonpea Newsletter 3, 97-98

Mohan, S., Subba Rao, P. V, and Sundara Babu, P. C. (1994) A new model trap for monitoring pigeonpea pod fly. International Chickpea and Pigeonpea Newsietter 1, 42

Naresh, J. S., Sharma, S. S. and Dahiya, B. (1983) Assessment of losses caused by Heliothis armigera and Melanagromyza obtusa in 8 varieties of pigeonpea in Haryana. Indian Journal of Plant Protection 11, 37-39

Naresh, J. S. and Singh, J. (1984) Population dynamics and damage of insect-pests in flowering Pigeonpea (Cajanus cajan (L.) Millsp.). Indian Journal of Entomology 46, 412-420

Nene, Y. L. and Sheila, V. K. (1990) Pigeonpea: Geography and importance. In The Pigeonpea, ed. Y. L. Nene, S. D. Hall and V. K. Sheila, pp. 1-14. CAB International, Wallingford

Neupane, F. P. (1993) Insect pests of crop plants in Chitwan. In LAAS Research Reports (1985-91), ed. F. P. Neupane, pp. 493-526. Institute of Agriculture and Animal Science, Rampur, Chitwan, Nepal

Odak, S. C, Thakur, B. S., Laxman Singh and Shrivastava, M. P. (1976) Status and distribution of pod infesting insect species of pigeonpea in Madhya Pradesh. Jawaharlal Nehru Krishi Vishwavidyalaya Research Journal, 10, 414-415.

Ortman, E. E. and Peters, D. C. (1980) Plant resistance to insect: theory and concept. In Breeding Plants Resistant to Insects, ed. F. G. Maxwell and P. R. Jennings, pp. 1-13. John Wiley and Sons, New York

Pandao, S. K., Mahajan, K. R., Muqeem, A., Aherkar, S. K. and Thakare, H. S. (1993) Efficacy of some insecticides against tur pod borers on semi rabi arhar (Cajanus cajan L.) var. C-11. Punjabrao Krishi Vidyapeeth Research Journal 17, 229-230

Pandey, S. N., Sarma, V. K., Singh, R., Kanwat, P. M. and Sharma, J. P. (1984) Infestation of tur podfly Melanagromyza obtusa Malloch in medium maturing varieties of pigeonpea Cajanus cajan (L) Millsp.. Indian Journal of Entomology 46, 372-374

Patel, J. R. and Patel, R. C. (1983) Note on varietal susceptibility and extent of damage of podfly, Melanagromyza phaseoli Tryon to pigeon pea. Indian Journal of Entomology 45, 314-316

Patel, R. K. and Verma, M. L. (1973) Occurrence of Melanagromyza obtusa (Malloch) on bhindi. Journal of the Bombay Natural History Society $\mathbf{7 0 , 4 0 6}$
Patil, C. S., Khaire, V. M. and Mote, U. N. (1990) Comparative performance of different insecticides against pigeonpea pod borer complex on short duration pigeonpea. Journal of the Maharashtra Agricultural Universities 15, 337-339

Patnaik, H. P. and Patnaik, N. C. (1985) Relative susceptibility to the podfly of certain early-maturing pigeonpea cultivars. International Pigeonpea Newsletter 4, 50-51

Peter, C. (1992) A note on the parasitoid fauna associated with red gram pod fly Melanagromyza obtusa Malloch. Jouranal of Insect Science 5, 88

Prasad, S., Prakash, R. and Hassan, M. A. (1972) Natural crossing in pigeonpea (Cajanus cajan (L.) Millsp.). Mysore Journal of Agricultural Science 6, 426-429

Prasad, Y. G, and Singh, Y. (1992) Chemical control of insect pests of pigeonpea, Cajanus cajan (L.) Millsp. Indian Journal of Entomology 54, 312-320

Rangajah, P. V. and Sehgal, V. K. (1986) Insects on T 21 pigconpea and losses caused by them at Pantnagar, northern India. International Pigeonpea Newsletter 3, 40-43

Rawat, R. R. and Jakhmola, S. S. (1967) Fstimation of losses in grain yield in different varieties of Tur (Cajanus cajan) by pod fly, plume moth, pulse beetle and other means. Madras Agricultural Journal 54, 601-602

Reddy, A. R., Venkateswarlu, S. and Singh, O. N. (1981) Pattern of podfly and podborer damage in the late pigeonpea. In Proceedings of the International Workshop on Pigeonpeas, Vol. 2. pp. 323-327. Patancheru, Andhra Pradesh, India

Reed, W. and Lateef, S. S. (1990) Pigeonpea: Pest management. In The Pigeonpea, ed. Y. L. Nene, S. D. Hall and V. K. Sheila, pp. 349-374. CAB International, Wallingford

Sachan, J. N. (1995) Entomology - Consolidated report on Kharif puises, 1994-95. Kharif pulses group meet, April 26-29, 1995. All-India Co-ordinated Pulses Improvement Project, Indian Council of Agricultural Research

Sah, B. N. and Mehra, B. P. (1986) New record of the parasites of Melanagromyza obtusa Malloch in Ranchi India. Indian Journal of Entomology 48, 359

Sahu, H. R., Parsai, S. K. and Choudhary, R. K. (1991) Bioefficacy and economics of certain insecticides against pod infesting pests of pigeonpea Cajanus cajan (L.) Millsp. Indian Joumal of Plant Protection 19, 37-41

Sasakawa, M. (1963) Papuan Agromyzidae (Diptera). Pacific Insects 5, 489-506

Saxena, K. B., Singh, L., Reddy, M. V., Singh, U., Lateef, S. S., Sharma, S. B. and Remanandan, P. (1990) Intra species variation in Atylosia scarabaeoides (L.) Benth., a wild relative of pigeonpea (Cajanus cajan (L.) Millsp.). Euphytica 49, 185-191

Sebastian, P. C. (1993) A study on the parasitoids of pigeonpea podfly, Melanagromyza obtusa (Malloch), in Kerala. Indian Joumal of Entomology 55, 158-161

Sehgal, V. K. (1965) Studies on Indian Agromyzidue (Diptera)-2. Beiträge zur Entomolgie 15, 1/2 3-10

Sehgal, V. K. (1987) Agromyzidae (Diptera) of economic importance in India and their management. In Recent Advances in Entomology, ed. Y. K. Mathur, pp. 111-140. Gopal Prakashan, Kanpur, Uttar Pradesh, India

Sehgal, V. K. (1990) Agroecological pest management in chickpea and pigeonpea crops in India. In Proceedings of the 3 rd International Conference on Plant Protection in the Tropics, Vol, 5, pp. 74-79. Malaysian Plant Protection Society, Kuala Lampur, Malaysia

Sharma, R. P. and Singh, O. (1984) Incidence of Melanagromyza obtusa (Mall.)(Diptera: Agromyzidae) on summer okra at Rewa Madhya Pradesh. Indian J. Agric. Sci. 54, 1010-1011

Singh, D. (1991) Three hymenopterous parasitoids of Melanagromyza obtusa (Malloch), a pest of tur, Cajanus cajan (L.) Millsp. Journal of Entomological Research 15, 282-286 
Singh, D. (1992) Relationship between the incidence of pod infestation of Cajanus cajan (L.) Millsp. by Melanagromyza obtusa (Malloch) and the rate of parasitism. Journal of Entomological Research 16, 166-171

Singh, H. M., Singh, R. and Rizvi, S. M. A. (1988) Insecticidal evaluation against pigeonpea pod borers. Indian Journal of Plant Protection 16, 217-220

Singh, N. N. and Rai, L. (1984) Biological studies of Melanagromyza obtusa (Malloch) on Cajanus cajan (L.) Millsp. Bulletin of Entomology 25, 156-161

Singh, N. N. and Rai, I. (1985) Ffficacy of certain insecticides against podfly under different spraying schedules. Indian Journal of Entomology 47, 268-273

Singh, O. P., Budhraja, K. and Misra, U. S. (1984) Ovicidal effect of various insecticides on the eggs of Melanagromyza obtusa (Mall.) (Diptera: Agromyzidae), a pest of pigeonpea. Indian Journal of Agricultural Science 54, 997-1000

Singh, O. P., Kapoor, K. N., Dhamdhere, S. V. and Misra, U. S. (1982) Note on the ovipositional behaviour of pigeonpea podfly, Melanagromyza obtusa (Malloch). Indian Journal of Agricultural Science 52, 267-268

Singh, R. N. and Singh, K. M. (1978) Influence of intercropping on succession and population build up of insect-pests in early variety of red gram Cajanus cajan (L.) Millsp. Indian Journal of Entomology 40, 361-375

Singh, R. P., Singh, Y. and Singh, S. P. (1985) Field evaluation of neem Azadirachta Indica A. Juss seed kernel extracts against the pod borers of pigeonpea, Cajanus cajan (L.) Millsp. Indian Joumal of Entomology 47, 111-112

Singh, S. and Ipe, I. M. (1973) The Agromyzidae from India. Memoirs of the School of Entomology 1. St. John's College, Agra, Uttar Pradesh, India

Singh, S. and Singh, S. P. (1991) Bioecology of Ormyrus orientalis Walker) (Family Ormyridac), a kcy parasitc of Melanagromyza obtusa (Malloch). In Bioecology of Hymenoptera Parasites of Agromyzidae (Diptera) Pest Species in India, ed. S. Singh, S. P. Singh, S. Suresh Babu and P. C. Sebastian, pp. 29-75. Memoirs of the School of Entomology 11, St. John's College, Agra, Uttar Pradesh, India

Singh, S., Singh, S. P., Suresh Babu, S. and Sebastian, P. C. (1991) Bioecology of Hymenoptera Parasites of Agromyzidae (Diptera) Pest Species in India. Memoirs of the School of Entomology 11, St. John's College, Agra, Uttar Pradesh, India

Singh, S. P. (1994) Studies on hymenopterous parasites of Melanagromyza obtusa (Malloch) (Diptera, Agromyzidae), a pest of Cajanus cajan Spreng., in India. Anzeiger für Schadlingskunde Pflanzenschutz Umweltschutz 67, 19-21

Singh, S. P. and Manwani, P. (1993) Studies on immature stages of Senegalella sp. (Hymenoptera: Torymidae), a parasite on the larvae of Melanagromyza obtusa (Malloch) (Diptera: Agromyzidae). Himalayan Journal of Environmental Zoology 7, 162-165

Singh, Y. and Singh, S. P. (1986) Ovipositional preference of Callosobruchus chinensis linnaeus and viability of damaged grains of pigeonpea by podfly Agromyza obtusa (Malloch). Indian Journal of Entomology 48, 324-328

Sinha, M. M. and Srivastava, S. N. (1989) Spray schedule for pod borers of pigeonpea. Legume Research 12, 101-102

Sithanantham, S., Lateef, S. S. and Reed, W. (1981) Podfly susceptibility in pigeonpea: Some aspects of oviposition preference. In Proceedings of the International Workshop on Pigeonpeas, Vol. 2, pp. 329-335. Patancheru, Andhra Pradesh, India

Sithanantham, S., Rameshwar Rao, V. and Reed, W. (1983) Survey of pigeonpea podfly parasites in India. International Pigeonpea Newsletter 2, 66-68

Sithanantham, S., Rameshwar Rao, V. and Reed, W. (1987) Parasites of the pigeonpea podfly, Melanagromyza obtusa (Malloch), in India. Iournal of Biological Control 1, 10-16

Sithanantham, S., Rameshwar Rao, V., Srivastava, C. P. and Reed, W. (1988) Developing traps to monitor adult pigeonpea podflies. International Pigeonpea Newsletter 8, 14
Sithanantham, S. and Sehgal, V. K. (1985) A survey for offseason survival of pigeonpea podfly around Pantnagar India. International Pigeonpea Newsletter 4, 53-54

Sithanantham, S. and Singh, H. (1986) Podfiy damage on latematurity pigeonpea at and around Gwalior. International Pigeonpea Newsletter 5, 40-42

Sontakke, B. K. and Mishra, P. R. (1991) Comparative efficacy and economics of synthetic pyrethroids in the management of pod borer complex of pigeonpea. Indian Joumal of Plant Protection 19, $167-170$

Spencer, K. A. (1973) Agromyzidae (Diptera) of Economic Importance. Dr W. Junk B.V., The Hague

Srivastava, A. S. and Srivastava, J. L. (1966) Insecticide trial against Agromyza obtusa M. (Diptera: Agromyzidae). Labdev Journal of Science and Technology 2, 4 133-135

Srivastava, C. P., Rameshwar Rao, V., Sithanantham, S. and Pimbert, M. P. (1991) Preliminary observations on pattern of podfly oviposition in two pigeonpea cultivars at Gwalior. International Pigeonpea Newsletter 14, 27-29

Srivastava, K. P., Agnihotri, N. P., Gajbhiye, V. T. and Jain, H. K. (1984) Relative efficacy of fenvalerate, quinalphos and neem kernel extracts for the control of pod fly, Melanagromyza obtusa (Malloch) and pod borer, Heliothis armigera Hubner infesting red gram, Cajanus cajan (L.) Millsp. together with their residues. Journal of Entomological Research 8, 1-4

Sundara Babu, P. C. and Rajasekaran, B. (1984) Studies on the control of pod borers and pod fly on redgram (Cajanus cajan L.) Pesticides 18, 2 24-26

Talekar, N. S. (1988) A note on the concurrence of Melanagromyza obtusa in Taiwan. International Pigeonpea Newsletter 7, 34

Talekar, N. S. (1990) Agromyzid Flies of Food Legumes in the Tropics. Wiley Eastern Ltd, New Delhi

Thakre, S. M., Khan, K. M. and Borle, M. N. (1981) Efficacy of some insecticides in the control of pod borer complex on arhar Cajanus cajan. Punjabrao Krishi Vidyapeeth Research Journal 5, 193-196

Thakur, B. S. and Odak, S. C. (1982) New record of the parasites of Melanagromyza obtusa Malloch. Science and Culture 48, 80

Thakur, B. S., Rawat, R. R., Verma, R. and Moitra, A. (1989) Influence of shape and size of pods of Cajanus cajan (L.) Millsp. on the susceptibility to the pod fly, Melanagromyza obtusa Malloch and the pod bug Clavigralla gibbosa Spinola. Indian Journal of Entomology 51, 159-162

Thevasagayam, E. S. and Canagasigham, L. S. C. (1960) Some observations on the insect pests of dhal (Cajanus cajan) and their control. Tropical Agriculturist 116, 287-298

Tripathi, R. K. and Prohit, M. L. (1983) Pest damage on pigeonpea in relation to pod size and colour. Legume Research 6 103-104

Veda, O. P. and Shaw, S. S. (1992) Interaction of pod infesting insects to pigeonpea. Indian Journal of Pulses Research 5, 212-213

Veda, O. P., Purohit, M. L. and Sood, N. K. (1975) Varietal susceptibility of arhar (Cajanus cajan (L.) Millsp.) to Melanagromyza obtusa Mall.; Exalastis atomosa Wlsm. and Heliothis armigera Hub. Jawaharlal Nehru Krishi Vishwavidyalaya Research Journal 9 7-9

Venugopal, S. and Venkataramani, K. S. (1954) An agromyzid insect pest of bhindi. Journal of Madras University (B) 24, 335-340

Veeraswamy, R. (1959) Influence of early sowings on the incidence of 'red gram pod fly' (Agromyza obtusa Mall.) on redgram (Cajanus indicus Spreng.). Madras Agricultural Journal 46, 99-101

Yadava, C. P., Lal, S. S. and Sachan, J. N. (1988) Assessment of incidence and crop losses due to pod-borers of pigeonpea (Cajanus cajan) of different maturity groups. Indian Journal of Agricultural Science 58, 216-218

Yadava, C. P., Lal, S. S., Dias, C. A. R. and Nigam, R. (1983) Host evasion - a prospective approach for suppressing Heliothis damage. International Pigeonpea Newsletter 2, 62-64 
Yadava, C. P., Lal, S. S., Dias, C. A. R. and Nigam, R. (1983)

Field tests of monocrotophos for control of the pod fly Melanagromyza obtusa Malloch infesting pigeonpea. Indian Joumal of Plant Protection 11, 6--8
Yadav, L. S., Chaudhary, J. P. and Yadav, P. R. (1992) Effect of crop management practices on the incidence of Melanagromyza obtusa Malloch in pigeonpea. Indian Journal of Entomology 54, $109-114$ 